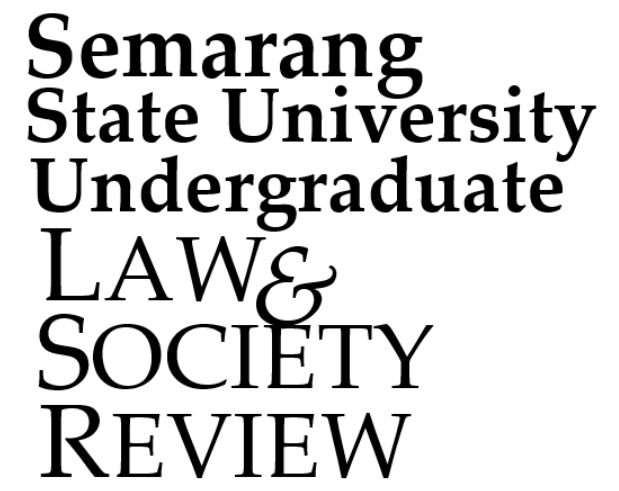

VOLUME 1 ISSUE 1, JANUARY 2021
ISSN (Print): 2807-8225 ISSN (Online): XXXX-XXXX

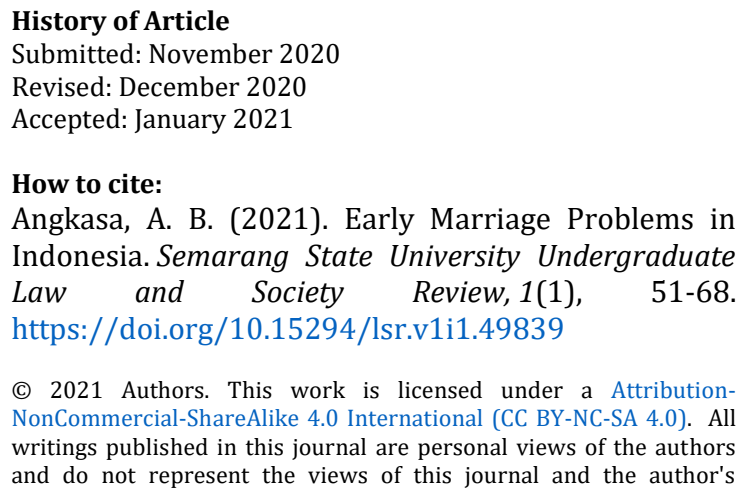

Angkasa, A. B. (2021). Early Marriage Problems in Indonesia. Semarang State University Undergraduate Law and Society Review, 1(1), 51-68. https://doi.org/10.15294/lsr.v1i1.49839

(C) 2021 Authors. This work is licensed under a AttributionNonCommercial-ShareAlike 4.0 International (CC BY-NC-SA 4.0). All writings published in this journal are personal views of the authors and do not represent the views of this journal and the author's affiliated institutions.

\title{
Early Marriage Problems in Indonesia
}

\author{
Aghnat Bintang ANGKASA® \\ Universitas Negeri Semarang \\ Jl. Kampus Timur, Sekaran, Gunungpati, Semarang, INDONESIA \\ 凶aghnatbintang@gmail.com
}

\begin{abstract}
Marriage in Indonesia is based or regulated in Act No. 1 of 1974 concerning Marriage. In Chapter 2, article 7, paragraph 1 reads "Marriage is only permitted if the man has reached the age of 19 (nineteen) years and the woman has reached the age of 16 (sixteen) years". In this paper I will discuss about marriage at a young age or what we are familiar with the term early marriage. The main factor of early marriage is the role of parents in family communication. In this study it is hoped that the community in particular the parents (family) can increase the support and care for the teenagers to be better in the future.
\end{abstract}

KEYWORDS. Family Law; Early Marriage; Child Marriage; Child Protection 


\section{INTRODUCTION}

Marriage, which means marriage is the bond inner between a man and a woman as husband and wife in order to form a happy and eternal family based on the One Godhead (Sudarsono, 2005). Thus, marriage is a contract which in its whole aspect is contained in the word marriage and is a sacred utterance ceremonial (Wantjik, 1990).

The family is a social institution is universal, located in all layers and groups of people in the world, in addition to religion. Family is a miniature of society, nation, and Country (Satrio, 1998). Both institutions, families and religions are the institutions most heavily buffeted by the flow of globalization and modern life. In the era of globalization, people's lives of people's lives tend to be materialistic, individualistic, social controls are weaker, marital relationships are more tolerable, the relationship of children with parents shifts, the sanctity of families is increasingly depleted (Dwinanda, 2015).

Early marriage is a formal or informal marriage performed under the age of 18 years (Satrio, 1998). One factor of other early marriage is adolescent education and parent education. In one's life, in addressing problems and making decisions including more complex matters or psychosocial maturity is strongly influenced by one's education level (Wantjik, 1990). Low level of education and knowledge of children can cause a tendency to marriage at an early age (Desiyanti, 2015).

Young adolescents with low education have a risk 4,259 times for early marriage than young teenagers who are highly educated. Adolescents with a high educational background have a lower risk of early marriage compared with adolescents with low educational background. Level of education is one of the factors that affect a person in addressing the problem and make decisions or psychosocial maturity. Parental education also has a role in decisions for children, because in this family environment, the first and foremost children's education (Desiyanti, 2015). 
Juspin argued that the role of parents to the continuity of early marriage is basically inseparable from the level of knowledge parents are also associated with the level of parent education. there is a relationship between parent education in young adult women with a risk of 7.667-fold. Teenagers who have a background of poorly educated parents then have a greater risk for early marriage than teenagers who have a background of educated parents. One of the factors that can influence the decision of the parents to their children one of which is the prominent factor of family education (Desiyanti, 2015).

\section{MARRIAGE: A LEGAL PROCEDURE}

Some authors mention marriage with the word marriage. In the Indonesian language, "marriage" is derived from the word "mating", which, according to language, means to form a family of the opposite sex; sexual intercourse and intercourse, "the term" mating "is used in general, for plants, animals, and humans, and shows generative processes naturally. In contrast, marriage is only used in humans because it contains legitimacy in national law, customs, and especially according to religion. The meaning of marriage is a contract or a bond, because in a marriage process there is a consent (statement of submission from the woman) and Kabul (statement of receiving from the men). In addition, marriage can also be interpreted as intercourse (Mafhudin, 2016).

The Civil Code does not provide any understanding of marriage. Marriage in civil law is a civil marriage, meaning that marriage is only an outward bond between man and woman, the element of religion is not seen (Saebani, 2009).

On the contrary, Article 1 of Law Number 1 Year 1974 states that marriage is an inner bond between men and women in order to form a happy and eternal family based on the One Godhead (Law No. 1 of 1974). Marriage under Law No. 1 of 1974 is not only an outward bond, but also an inner bond, where the bond is based on the belief of a husband and wife. 
According to Article 2 of Law Number 1 Year 1974, marriage is lawful if done according to the law of their respective religions and beliefs.

In marriage have full freedom to declare whether they are willing or not. The agreement is expressed in the form of a consent and qabul which must be uttered in one assembly, either directly by the person concerned, i.e., the prospective husband and the future wife, if both are entitled entirely to him according to law or by those authorized for it. Otherwise, the case is in a state of insanity or underage, for them to act their legal guardians. The procedure of marriage is four ways:

1) Reports

2) Announcement

3) Prevention

4) Continuation

Any person who will make a marriage in advance notifies his / her wish to the recording officer at the place of marriage shall be held no later than 10 working days before the marriage takes place (Saeani, 2009). Such notice shall be made verbally and in writing by the prospective bride or parent or representative. The notice shall contain the name, age, religion / belief, occupation, place of residence of the prospective bridegroom, and if either or both of them have ever mentioned the name of their spouse or previous husband.

The recording officer will research the notices. If the procedures and conditions of notification have been met and there is no marriage barrier, then an announcement will be made. Announcements are attached to a designated place for easy public reading.

If nobody does the prevention of marriage, then marriage in accordance with the law and religion of belief respectively before the clerk employee and attended by two witnesses. After the marriage of the bride, two witnesses, and the recording officer sign the marriage certificate to be declared official.

The marriage certificate is made in duplicate. The first is kept by the recording officer and the other is kept by the court clerk within the territory 
of the marriage register. All husbands and wives are each given a quote from the marriage deed (Syarifudin, 2005).

\section{AN EARLY MARRIAGE IN ISLAMIC LAW}

The view of the jurists on the marriage of minors, in the decree Ijtima "scholars" commission in Indonesia in 2009 stated that in the literature of Islamic figh, there is no provision explicitly about the age of marriage boundary, either the minimum age or maximum (Saebani, 2009). Nevertheless, the wisdom of tasyri "in marriage is to create a sakinah family, in order to obtain offspring and this can happen at an age where the prospective bride has perfect mind sense and ready to perform the process of reproduction (Shufiyah, 2018).

Based on this, the fatwa commission has already established several laws, firstly Islam does not provide a minimum age of marriage in difinitif, appropriate age for marriage is the age of the ability to do and receive the right as a provision. Secondly, underage marriage is legal as long as it has fulfilled the terms and conditions of marriage but it is haram if it only produces a lot of mudharat. Third, the maturity level of age is one indicator for the achievement of the purpose of a marriage, namely kemaslahatan household and community life and security guarantees for pregnancy. Fourth, In order to realize the benefit of the marriage provision is returned to the age readiness as stipulated in Law No. 1 of 1974 as a guide (Alfa, 2019; Musfiroh, 2016). The arguments on which the provisions of the law are stipulated are contained in the Qur'an an an Nisa verse 6, the letter At Thalaq verse 4, the letter An Nur verse 32, the hadith of Muttafaq Alaih from Aisha, the hadith of Bukhari and the Muslim of Al Qamah, the rules of fiqh in Qawaid Ahkamfi Al Anam by Izzudin Abd Al Salam Volume I, page 51, the jumhur fuqaha view which permits underage marriage, the views of Ibnu Shubrumah and Abu Bakr Al Asham, and Ibn Hazm's opinion that separates between the marriage of little boys and little girls (Syarifudin, 2005). 
The marriage of a young daughter by her father is permissible, while the marriage of a young son is not permitted (Prakoso \& Murtika, 1978). The decision of the MUI fatwa commission is in line with the opinion expressed by Asrorun Niam Sholeh that in the Islamic fiqh literature there is no rule concerning the age of marriage, so marriage by an elderly person is deemed legitimate when it meets the terms and conditions, as will also be valid young children. In general in Islamic law concerning underage marriage, fuqaha categorizes in three groups. The jumhur fuqaha's view of underage marriage is permissible, although the permissibility of underage marriage does not necessarily allow for intercourse. If there is a relationship will result in the existence of dharar, it is forbidden, both at the early age and for the adults (Soekanto \& Mamudji, 1985).

In the view of Ibn Shubrumah and Abu Bakr Al Asham, it is stated that underage marriage is forbidden. In the view of Ibn Hazm, he took between the marriage of the little boy and the marriage of the little girl. The marriage of a young girl is permitted by her parents while a small boy is not allowed. The basis is the zahir of the hadith of marriage between Aishah and the Prophet Muhammad SAW. So in the discourse of jurisprudence, there is no rule that determines the age limit of marriage. Therefore, according to figh all ages can marry on the basis that it has been able to biologically, physically, and mentally. However, better marriages are performed when they are old enough and mature in body and spirit. Included in the effort to foster a quality family should husband and wife should be supported by some ability, first physical and spiritual ability, this is translated with the terms baligh and mukalaf. Second obligation to give a living. A husband is obliged to give a living to his wife and children well. Thirdly, mothers should take their children for about two years, that is for those who want to improve breastfeeding. And the duty of the father to feed and the proper clothes to the mothers in a ma'ruf (good) way (Hastuti \& Aini, 2016; Shufiyah, 2018). 


\section{UNDERAGE MARRIAGE UNDER LAW NUMBER 1 OF 1974}

Among the features of Islam is universality, flexibility, rational, in accordance with place and time and easily accepted, whether related to the problem of worship, muamalat, morals and related marriage law. The issue of early marriage is often a controversy in society because there is still the view that it is allowed in religion, and exemplified the Prophet Muhammad. If we see from the Law of the State there are compulsory courses in Indonesia that have been initiated since 1950.

In Law number 4 of 1950 jo Act Number 12 of 1954 has been determined that every child aged 8-14 years must follow compulsory education. The ultimate goal is to have children have the opportunity to attend education until the age of 15 , and as a basis for further study both in higher education and in the workplace. There are 1945 Constitution article 31 paragraph 1 and 2, then based on RI Law No. 20 of 2003 on how the national education system, the main goal of national education has been established to develop the ability and shape the character and also dignified nation civilization in order meencerdaskan life of the nation, for the development of insight learners to be human beings who believe and fear God Almighty, have noble character, knowledgeable, skilled, creative, independent and become a good citizen and have a sense of responsibility (Fedyana, 2009; Julianto, 2015).

The existence of Government Regulation No. 9/1975 on the implementation of Law No. 1 of 1974 concerning the marriage of Chapter 2 of Article 6 no 2 (c) written permission / court permit as referred to in Article 6 paragraph (2), (3), 4) and (5) of the Act, if one of the prospective bridegroom or both has not reached the age of 21 years. Article 2 of the Marriage Act No. 1 of 1974 states that "Marriage is lawful, if done according to the law of their respective religion and belief." 
Thus marriage shall be valid if it is done in a religious law, which means that the married party shall adopt the same religion If there are different religions, one of them must follow the religion of the other party so that the parties hold marriage ased on the law of one religion and 21 years old if not reach 21 years must get permission from both parents (Subekti, 2010; Suhadi, 2012; Suhadi, Baidhowi, \& Wulandari, 2018).

\section{FACTORS OF EARLY MARRIAGE PROBLEMS THAT OCCUR IN INDONESIA}

1) Internal factor (from the Actor)

Early marriage among teenagers is also derived from the child's selfwill. This is because both already love each other, it will arise willing to get married regardless of their age. In a sense of mutual love and they feel it is appropriate it will soon get married, without them thinking of the problem problems that will arise in the family world. If both do not have enough age to marry it will have a negative impact on their family in the future.

2) Parent factor

Family factor is one factor of the occurrence of marriage of young age, where families and parents used to marry off their children when it was the age of adulthood. This is a very easy thing we meet or hereditary. A family with a daughter will not feel at ease when her daughter marries. Parents will be worried and afraid if their children do things that are not desirable that will contaminate the good name of his family.

3) Economic problem factor

Poverty is already a common cause of the underlying cause of marriage. The reason for securing the future of the girl, both in financial and in social, and most importantly, in a marriage will benefit the parents of the dowry to be paid by the men. In addition there are also 
traditions that assume that should not reject an application, there is also a thought can reduce the burden of the family. Circulating news in the community that girls in poor families will only increase the burden of the family. Therefore, marriage at a young age is considered to be a solution to replace all living expenses that have been issued by his parents and exchanged with dowry from the male side.

4) Educational factors

Education is one of the factors that influence one's thinking, with a high education then one will be easier in accepting the changes if it makes him better. Because the level of education itself describes the level of a person's personality in looking at the surrounding environment that can affect insight thinking about the existing knowledge in the environment. The economic level of the family is very influential also on the education level of family members. The low income of the family may be a reason for the child to drop out of school so that he can not continue his higher level education. The main factor of mating age is low access to education. Because of the low education comes from the inability to finance the education of family members.

5) Cultural factors

In many societies in Indonesia there has been a matchmaking of their daughters since they were children. And will be married when they are menstruating, in this case the woman's curiosity will menstruate at the age of 12 years. And that will result at the age of 12 years that they will soon be married to the candidate mate. it causes him to marry at the age of 12 years that itself is very far from the age set in the law.

\section{THE CONSEQUENCES OF UNDERAGE MARRIAGE}

1) Influence on children from young couples

Problems that will arise in young couples of course not only affect both couples, but also on their children. Because it will be risky to women 
who gave birth to children under the age of 20 years. And it usually will experience disruption of the fetus that is conceived which will certainly cause health problems in the child (Subekti, 2010; Suhadi, 2012).

2) Impact on the household of young couples

Lots of people who have been married and do not think about the problems that will arise after officially became a married couple by age. In addition to causing problems for couples, the problem will also affect their children, it is very dangerous because the child will be very easy to imitate the things exemplified by his parents (Jannah, 2012).

3) Problems arising in the midst of the family

Marriage at such a young age can also affect both sides of the family, both the woman's and the men's family, because if there is a problem and they can not solve the problem, what will happen is a divorce. That will cause grief in both families of their parents (Subekti, 2010; Jannah, 2012).

4) Psychological Effects that Will Arise due to Early Marriage

In marriages that tend not to enter a mature age will cause many problems one of them is a psychiatric problem in couples. At an age that is not enough, and a wife already contains it will cause prolonged trauma, because he felt not yet time to live it. And it will have an impact on his confidence, it will cause a confidence crisis. Children in psychology are also not ready to play a wife, partner sex, and certainly become a mother. So obviously early marriage has the potential to cause a negative impact on psychological well-being and the development of their personalities (Jannah, 2012).

5) Children Born from Early Marriage

As a growing child experiences the process of pregnancy, there is a nutritional competition with the fetus it contains, so the pregnant women's weight is often difficult to rise, may be accompanied by anemia due to nutritional deficiency, and the risk of delivering a baby 
with low birth weight. It was found that about $14 \%$ of babies born to teenage mothers under 17 years old are premature.

Furthermore, it is also emphasized that Pelvic anatomy is still at risk for prolonged labor, increasing infant mortality and neonatal death. Depression at the time of pregnancy is at risk for the incidence of miscarriage, low birth weight and others.

Depression is also associated with an increase in blood pressure, thereby increasing the risk of eclamps endangering the fetus and the mother who contains it. Good antenatal care can actually reduce the occurrence of complications of pregnancy and childbirth. Unfortunately, due to financial limitations, limited mobility and opinion, these young wives often do not get the health care they need, thereby increasing the risk of maternal and mortality complications. Being a parent at an early age with less skill to parenting a child as an adult may place a born child at risk of mistreatment and / or neglect. Various studies show that children born from early marriage risk experiencing developmental delays, learning difficulties, behavioral disorders, and tend to be parents also at an early age (Fedyana, 2009; Ilahi, 2021).

\section{THE ROLE OF PARENTS IN BUILDING COMMUNICATION SYSTEMS IN THE FAMILY}

The role of parents in building communication in a family is an important thing that must be known by the parents. It is best to familiarize children as young as to share stories, because children will get used to telling parents, so there are many problems that will be easy to solve together. Because many parents today are just ignorant of the problems that are owned by children and most parents now tend to be closed with their children. And that's what makes children now also inclined not to talk 
about the problems they have. And parents sometimes have less time for children, less knowledgeable about the world of playground information, their friends, and even their child's boyfriends. So that causes communication in the family to be not formed (Jannah, 2012; Pratiwi, 2020).

As in a system with each other will be interconnected then the son as part of the family requires the presence of parents not only from the physical form but also in terms of thought. Communication between parents of both father and mother is considered to be less important. As part of an open system a child who is at a young age has an opportunity to interact with others. The interaction was obtained from outside members of the family such as friends, extended family, friends, girlfriends, or even teachers.

As a less than optimal system, the decision of the child to marry at an early age is the result that will be caused by the not optimal system in the family. Teenagers tend to choose to communicate with people outside family members, without thinking ahead that any interaction actions done with others have a certain effect. One of the impacts that will arise is marriage at an early age and some or even usually preceded by an unplanned pregnancy (Abdullah, 2009; Nugraha, Izzaty, \& Putri, 2019).

\section{LEGAL REVIEW IN EARLY MARRIAGE}

The Convention on the Rights of the Child applies as an international law and the CRC is ratified by Presidential Decree No.36 of 1990, hereafter ratified as Child Protection Law No.23 of 2002. The ratification of the Act aims to realize the protection and welfare of children. It is clearly stated in the Law on the Law that the Unitary State of the Republic of Indonesia guarantees the welfare of each of its citizens, including the protection of the rights of the child which is a human right (Fedyana, 2009)

The Convention on the Rights of the Child has become part of the national legal system, so as a consequence we are obliged to recognize and 
fulfill the rights of the child as defined in the CRC. One of the principles in the CRC is "the best interests of the child". The purpose of the principle of "the best interests of the child" is that in all child-related acts committed by the government, the public, the legislature and the judiciary, the best interests of the child shall be the primary consideration.

In Article 1 Paragraph 2 of Law No. 2 states that "child protection" is any activity to guarantee and protect children and their rights in order to live, grow, develop, and participate optimally in accordance with human dignity and values, and get protection from violence and discrimination (Abdullah, 2009; Latifiani, 2019).

In the declaration of human rights, it is said that marriage must be done with the consent of both partners. But the reality faced in this early marriage, marriage consent is often the accumulation of coercion or the pressure of the parent / guardian of the child, so the child agreeing to marriage is often a sense of devotion and respect for the parents. Parents think marrying their child means a form of protection against the child, but this actually causes the loss of a child's opportunity to grow, grow healthy, and lose the freedom of choice. Similar statements were also issued by the International Humanist and Ethical Union, that child marriage is a form of mistreatment in children. In this case, given the various consequences that the child faces in relation to the early marriage as discussed, then child marriage certainly causes the non-fulfillment of the principle "best for the child", so this is a violation of the human rights of the child (Arifin, Rodiyah, \& Putri, 2020).

The Child Protection Act clearly states the obligations of parents and the community to protect children, as well as the obligation of parents to prevent the occurrence of marriage at the age of the children (article 26). Criminal sanctions in the form of punishment of imprisonment and fines shall be stipulated in article 77-90 if violation of the child protection articles (Noviyanti, 2013; Christian \& Edenela, 2019). 


\section{CONCLUSION}

This study concluded that there is a relationship between the role of parents in family communication with the occurrence of early marriage which means that parents who lack a role have a greater chance to carry out an early marriage to their children than parents who have a good role. Poor economic conditions in a family is also one of the causes of early marriage, lack of insight a cause him to often think easy and tend not to think about things to come. They mostly only think about the results that will be in the can without thinking about the problem or the case going forward. Furthermore, it is also emphasized that there is a relationship between parental education and early marriage events which means that parents who have low education have a greater chance to carry out early marriage than parents who have a college education. Less education also to be a factor causing early marriage in Indonesia. Those who are less educated usually have a narrow mindset and are less able to solve problems that exist. They will also be difficult to adapt to the environment. Parents become the main factor of early marriage because parents are the ones who should manage the child's life from an early age. The personality of a child will be imitated from his or her parents. Because parents are actors in their lives. Parents should be able to improve communication in the family, so that the family becomes a perfect system. The decision to marry at an early age is the dilator's decision to be covered by various circumstances in a family, for example due to economic factors, educational factors, and communication between parents and their children. Most occur in adolescents who are in a sad economic condition, so they prefer to get married in order to get dowry to fulfil his life. Can also be caused by lack of communication between parents with their children. It will make the child become closed with his parents. 


\section{REFERENCES}

Abdulah, Z. A., Thata, R., \& Landing, J. (2009). Studi kasus pernikahan dini pada masyarakat Kecamatan Sanggalangi Kabupaten Tana Toraja. Jurnal MKMI, 5(4), 463-83.

Alfa, F. R. (2019). pernikahan dini dan perceraian di Indonesia. Jurnal Ilmiah Ahwal Syakhshiyyah (JAS), 1(1), 49-56.

Arifin, R., Rodiyah, R., \& Putri, F. R. A. (2020). The Legal and Social Aspect for Underage Marriage Women's Education Rights in the Perspective of Human Rights: Contemporary Issues and Problems. Sawwa: Jurnal Studi Gender, 15(2), 219-240.

Christian, J. H., \& Edenela, K. (2019). Terampasnya Hak-Hak Perempuan Akibat Diskriminasi Batas Usia Perkawinan. Lex Scientia Law Review, 3(1), 1-14.

Desiyanti, I. W. (2015). Faktor-faktor yang berhubungan terhadap pernikahan dini pada pasangan usia subur di Kecamatan Mapanget Kota Manado. JIKMU, 5(3).

Dwinanda, A. R., Wijayanti, A. C., \& Werdani, K. E. (2017). Hubungan antara pendidikan $\mathrm{Ibu}$ dan pengetahuan responden dengan pernikahan usia dini. Jurnal Kesehatan Masyarakat Andalas, 10(1), 76-81.

Fadlyana, E., \& Larasaty, S. (2016). Pernikahan usia dini dan permasalahannya. Sari Pediatri, 11(2), 136-41.

Hastuti, P., \& Aini, F. N. (2016). Gambaran terjadinya pernikahan dini akibat pergaulan bebas. Jurnal Riset Kesehatan, 5(1), 11-13.

Ilahi, A. H. A. (2021). The Evaluation of Early Marriage Law Renewal in Indonesia. Unnes Law Journal: Jurnal Hukum Universitas Negeri Semarang, $7(1)$.

Jannah, U. S. F. (2012). Pernikahan Dini dan Implikasinya Terhadap Kehidupan Keluarga Pada Masyarakat Madura (Perspektif Hukum dan Gender). Egalita: Jurnal Kesetaraan dan Keadilan Gender, 7(1), 83101. https://doi.org/10.18860/egalita.v0i0.2113 
Julijanto, M. (2015). Dampak Pernikahan Dini dan Problematika Hukumnya. Jurnal Pendidikan Ilmu Sosial, 25(1), 62-72.

Latifiani, D. (2019). The Darkest Phase for Family: Child Marriage Prevention and Its Complexity in Indonesia. JILS (Journal of Indonesian Legal Studies), 4(2), 241-258.

Law Numbe 1 of 1974 concerning Marriage (Marriage Law)

Mahfudin, A., \& Waqi'ah, K. (2016). Pernikahan Dini dan Pengaruhnya terhadap Keluarga di Kabupaten Sumenep Jawa Timur. Jurnal Hukum Keluarga Islam, 1(1), 33-49.

Muntamah, A. L., Latifiani, D., \& Arifin, R. (2019). Pernikahan dini di Indonesia: Faktor dan peran pemerintah (Perspektif penegakan dan perlindungan hukum bagi anak). Widya Yuridika: Jurnal Hukum, 2(1), $1-12$.

Musfiroh, M. R. (2016). Pernikahan Dini dan Upaya Perlindungan Anak di Indonesia. De Jure: Jurnal Hukum dan Syariah, 8(2), 64-73.

Noviyanti, W., \& Trihandini, I. (2013). Analisa Data Sekunder Survei Demografi Kesehatan Indonesia 2007: Tren dan Dampak Pernikahan Dini. Jurnal Fakultas Kesehatan Masyarakat: Universitas Indonesia, 5(1), 118.

Nugraha, X., Izzaty, R., \& Putri, A. A. (2019). Rekonstruksi Batas Usia Minimal Perkawinan Sebagai Bentuk Perlindungan Hukum Terhadap Perempuan (Analisa Putusan MK No. 22/Puu-Xv/2017). Lex Scientia Law Review, 3(1), 40-54.

Prakoso, D., \& Murtika, M. (1978). Asas Asas Hukum Perkawinan di Indonesia. Jakarta: PT. Bina Aksara.

Pratiwi, M. R. A. P. (2020). The Impact of Early Marriage in the Fulfilment of Women Rights. The Indonesian Journal of International Clinical Legal Education, 2(4), 449-462.

Saebani, B. A. (20209). Figh Munakahat 1. Bandung: Pustaka Setia.

Satrio, J. (1998). Asas Asas Hukum Perdata. Purwokerto: Hersa.

Shufiyah, F. (2018). Pernikahan Dini Menurut Hadis dan Dampaknya. Jurnal Living Hadis, 3(1), 47-70. 
Soekanto, S., \& Mamudji, S. (1985). Penelitian Hukum Normatif, Suatu Tinjauan Singkat. Jakarta: CV Rajawali.

Subekti, T. (2010). Sahnya Perkawinan Menurut Undang-Undang Nomor

1 Tahun 1974 Tentang Perkawinan Ditinjau Dari Hukum Perjanjian. Jurnal Dinamika Hukum, 10(3), 329-338.

Sudarsono, S. (2005). Hukum Perkawinan Nasional. Jakarta: Rineka Cipta.

Suhadi, S. (2012). Pernikahan Dini, Perceraian, dan Pernikahan Ulang: sebuah Telaah dalam Perspektif Sosiologi. Komunitas: International Journal of Indonesian Society and Culture, 4(2), 168776.

Suhadi, S., Baidhowi, B., \& Wulandari, C. (2018). Pencegahan Meningkatnya Angka Pernikahan Dini dengan Inisiasi Pembentukan Kadarkum di Dusun Cemanggal Desa Munding Kecamatan Bergas. Jurnal Pengabdian Hukum Indonesia, 1(01), 31-40.

Syarifudin, A. (2005). Garis Garis Besar Figh. Yogyakarta: Predana Media.

Wantjik, S. K. (1990). Hukum Perkawinan Indonesia. Jakarta: Ghalia Indonesia.

\section{Conflicting Interest Statement}

All authors declared that there is no potential conflict of interest on publishing this article.

\section{Funding}

None

\section{Publishing Ethical and Originality Statement}

All authors declared that this work is original and has never been published in any form and in any media, nor is it under consideration for publication in any journal, and all sources cited in this work refer to the basic standards of scientific citation. 
Much of the atrocities that are committed towards Arab women occur partly because the victim does not know that she has a basic right for her body to be hers, for her privacy to be respected and for her education to be a necessity not a privilege she receives if it is financially possible after her brother has been educated.

\section{Aysha Taryam}

Arab Feminist \& Activist for Women Protection 